\title{
C-Reactive Protein or Procalcitonin Combined with Rhinorrhea for Discrimination of Viral from Bacterial Infection in Hospitalized Adults of Non-Intensive Care Medical with Lower Respiratory Tract Infection
}

DUAN Shengchen ( $\nabla$ doctordsc@163.com)

Capital Medical University Affiliated Anzhen Hospital https://orcid.org/0000-0002-0918-8412

Xiaoying Gu

China-Japan Friendship Hospital

Guohui Fan

China-Japan Friendship Hospital

Fei Zhou

China-Japan Friendship Hospital

\section{Guangfa Zhu}

Capital Medical University Affiliated Anzhen Hospital

\section{Bin Cao}

China-Japan Friendship Hospital

\section{Research}

Keywords: C-reactive protein, procalcitonin, clinical characteristics, rhinorrhea, lower respiratorytract infection

Posted Date: June 15th, 2021

DOI: https://doi.org/10.21203/rs.3.rs-539293/v1

License: (1) This work is licensed under a Creative Commons Attribution 4.0 International License. Read Full License 


\section{Abstract}

Background: Whether procalcitonin (PCT) or C-reactive protein (CRP) combined with some clinical characteristics can better distinguish viral from bacterial infection is not clear. The aim was to assess the ability of PCT or CRP combined with clinical characteristics to distinguish between viral and bacterial infections in hospitalized non-intensive care unit (ICU) adults with lower respiratory tract infection (LRTI).

Methods: This was a post-hoc analysis of a randomized clinical trial previously conducted among LRTI patients. The ability of PCT, CRP, and PCT or CRP combined with clinical characteristics to discriminate between viral and bacterial infection were estimated by portraying receiver operating characteristic (ROC) curves among patients with only vial or typical bacterial infection .

Results: In total, 209 patients (virus $69 \%$, bacteria $31 \%$ ) were included in this study. When using CRP or PCT to discriminate between viral and bacterial LRTI, the optimal cut-off point were $22 \mathrm{mg} / \mathrm{L}$ and $0.18 \mathrm{ng} / \mathrm{ml}$, respectively. When the optimal cut-off for CRP $(\leq 22 \mathrm{ml} / \mathrm{L})$ or PCT $(\leq 0.18 \mathrm{ng} / \mathrm{ml})$ combined with rhinorrhea was used to discriminate viral from bacterial LRTI, the AUCs were $0.81(95 \% \mathrm{Cl}, 0.75-0.87)$ and $0.80(95 \% \mathrm{Cl}, 0.74-$ 0.86 ), respectively. When $C R P \leq 22 \mathrm{ml} / \mathrm{L}, \mathrm{PCT} \leq 0.18 \mathrm{ng} / \mathrm{ml}$ and rhinorrhea were combined, the AUC was $0.86(95 \%$ $\mathrm{Cl}, 0.80-0.91)$, which was statistically significant higher than that when $\mathrm{CRP}(\leq 22 \mathrm{mg} / \mathrm{L})$ or PCT $(\leq 0.18 \mathrm{ng} / \mathrm{mL})$ was combined with rhinorrhea $(p=0.0107$ and $p=0.0205)$.

Conclusions: Either $\mathrm{CRP} \leq 22 \mathrm{mg} / \mathrm{L}$ or $\mathrm{PCT} \leq 0.18 \mathrm{ng} / \mathrm{mL}$ combined with rhinorrhea could help distinguish viral from bacterial infection in hospitalized non-ICU adults with LRTI. When rhinorrhea was combined together, discrimination ability can be further improved.

\section{Background}

Lower respiratory tract infection (LRTI) is the most common infectious disease that may cause death, with about 3.0 million deaths worldwide in 2020.[1] Viral infection is one of the most important causes of LRTI. Identifying the pathogens involved timely is essential for antibiotics treatment, as detection delay may potentially result in antimicrobial resistance. Antimicrobial resistance can cause corresponding financial burden and environmental pollution, especially when antibiotics are inappropriately prescribed to patients with viral infection.[2]

Although some novel molecular diagnostic or culture-independent assays offer enhanced opportunities to identify respiratory pathogens, researchers are still pursuing much simpler, faster, and cheaper ways to identify different pathogens. Serum markers such as C-reactive protein (CRP) and procalcitonin (PCT), which can help guide antibiotic use in LRTI patients, have been studied most often.[3]' [4] But whether PCT or CRP could distinguish viral or bacterial infection is a controversial issue.[5]' [6]' [7]' [8] Furthermore, most of the studies have been hampered by an incomplete etiologic approach, because only a limited number of infectious agents have been assessed or techniques with low sensitivity have been used.[9]' [10] Consequently, those studies have not reported reliable information on the use of biomarkers for differentiating bacterial from viral LRTI.

Though some overlaps exist in symptoms and clinical presentation between bacterial and viral infection, viral infection has its own characteristic, such as headache, generalized muscle pain and rhinorrhea. One recently 
study showed that combination of clinical symptoms and blood biomarkers can distinguish bacterial from viral community-acquired pneumonia in children.[11] However, few studies have been conducted among adult LRTI so far.

The aim of this study was to assess whether PCT or CRP combined with clinical characteristics could distinguish between viral and bacterial infections using comprehensive and sensitive methods of etiologic classification in hospitalized non-intensive care unit (ICU) adults with LRTI.

\section{Methods}

This was a post-hoc analysis of a randomized controlled trial (RCT) that had been published previously.[12] The RCT took place between October 2017 and July 2018 in the China-Japan Friendship Hospital (CJFH), Beijing, China (clinicaltrials.gov identifier: NCT03391076). The study was approved by the ethics committee of CJFH (2017-29). Written informed consent was obtained from each participant after meeting the inclusion criteria.

\section{Study Population}

The inclusion criteria of the RCT study were as follows: hospitalized patients aged $\geq 18$ years who were preliminarily diagnosed as having radiographically confirmed community acquired pneumonia (CAP), acute exacerbation of chronic obstructive pulmonary disease (AECOPD), or acute exacerbation of bronchiectasis were recruited on the day of hospitalization. Patients were excluded if they were $<18$ years old, pregnant, had hospital acquired pneumonia, or lung tuberculosis. We also excluded immunosuppressive patients. In addition, patients with any other condition that may have increased serum PCT levels were also excluded. For this post-hoc analysis, Patients who did at least one bacterial and one viral test could be recruited in this study.

patients without CRP or PCT testing results, or without bacterial or viral pathogens detected were further excluded.

\section{PCT and CRP Measurement}

PCT or CRP concentrations were measured in the clinical laboratory of CJFH within 24 hours of admission. CRP was measured using the high sensitive-CRP Kit (i-Reader, China). The upper and lower detection limits were 200 $\mathrm{mg} / \mathrm{L}$ and $1 \mathrm{mg} / \mathrm{L}$, respectively. PCT was measured by use of the PCT Kit (i-Reader, China), with a detection limit of $0.01 \mathrm{ng} / \mathrm{mL}$.

\section{Pathogen Testing}

Bacterial testing included qualified sputum (defined as squamous cells < 10 per low-power field; polymorphonuclear leukocytes $>25$ per low-power field, or the ratio between the $2<1: 2.5$ ), lower respiratory tract samples and histological biopsy samples such as endotracheal aspiration, bronchoalveolar lavage fluid, and protected specimen brush or pleural fluid samples culture; blood culture; Streptococcus detected by urinary antigen (BinaxNOW, Alere). Atypical bacteria testing for Mycoplasma pneumoniae (MP) and Chlamydophila pneumoniae (CP) included reverse transcriptase polymerase chain reaction (RT-PCR) of sputum or other lower respiratory tract specimen samples; nasopharyngeal swabs used FilmArray Respiratory Panel for MP and CP; Urinary antigen for Legionella pneumophila (BinaxNOW, Alere). Mycobacterial testing included acid-fast bacillus 
culture and mycobacteria nucleic acid detection (Xpert MTB/RIF). Samples included Sputum, endotracheal aspiration, bronchoalveolar lavage fluid and protected specimen brush; blood, pleural effusion, bronchial mucosa biopsy; lung biopsy. Fungal testing included cultures of blood or other sterile samples such as pleural effusion, lung biopsy tissue samples, etc.

Viral testing included FilmArray Respiratory Panel of nasopharyngeal swabs for influenza $A(H 1$ and $H 3)$ virus, influenza B virus, respiratory syncytial virus, rhinovirus or enterovirus, human metapneumovirus, parainfluenza virus types 1-4, coronaviruses (OC43, 229E, HKU1, and NL63), and adenovirus; RT-PCR of sputum, nasopharyngeal swabs, or other lower respiratory tract specimen samples for influenza A (H1N1, H7N9) virus, influenza B virus, respiratory syncytial virus, parainfluenza virus, adenovirus, EpsteineBarr virus, herpes simplex virus, and human cytomegalovirus; rapid antigen assay of influenza virus (BinaxNOW, Alere) in oropharyngeal or nasopharyngeal swabs, or qualified lower respiratory tract.

\section{Statistical Analysis}

Patients were divided into two groups according to pathogen detection results. Those with bacteria detected and negative mycobacterial/fungal tests results, regardless of viral or atypical bacteria results, were classified into bacteria group. The other patients only with viruses detected were classified into virus group.

Baseline characteristics were expressed as number (proportion) or median (interquartile range) respectively and compared by $\chi 2$ test or Mann-Whitney $U$ test where appropriate. We then assessed the predictive performance of CRP, PCT and PCT combined with CRP for discriminating viral from bacterial infection by portraying receiver operating characteristic (ROC) curves, respectively. Optimal cut-points for CRP and PCT were defined as the point on the ROC curve that has the maximum Youden index. Furthermore, according to the optimal cut-points, the performance of PCT $\leq 0.18 \mathrm{ng} / \mathrm{L}, \mathrm{CRP} \leq 22 \mathrm{mg} / \mathrm{L}, \mathrm{PCT} \leq 0.18 \mathrm{ng} / \mathrm{L}$ and $\mathrm{CRP} \leq 22 \mathrm{mg} / \mathrm{L}$ combined with significant clinical features to discriminate viral and bacterial infection were evaluated. Sensitivity, specificity, positive predictive value (PPV), negative predictive value (NPV) and their 95\% confidence intervals (Cls) were calculated. The areas under the curve (AUCs) and 95\% Cls were estimated and compared to determine the different discriminations of models. A two-sided a less than 0.05 was considered statistically significant for all statistical tests. Statistical analyses were performed by the SAS software, version 9.4 (SAS Institute Inc.), unless otherwise indicated.

\section{Results}

Between Oct 16, 2017 and Jul 13, 2018, we recruited 800 patients in the previous RCT study. After excluding 129 patients without PCT or CRP, 39 patients with mycobacterial/fungal detected, and 423 patients with no pathogens detected, 209 patients were included in the current analysis. Of these patients, the viral group accounted for $69 \%$ and the bacteria group accounted for $31 \%$.

Baseline characteristics of study participants in viral and bacteria groups were shown in Table 1. The proportions of patients with headache or rhinorrhea were higher in patients infected with virus than that in patients infected with bacteria (36.6\%, 53/145 versus $18.8 \%, 12 / 64 ; \mathrm{p}=0.0104$ and $55.2 \%, 80 / 145$ versus $20.3 \%$, $13 / 64 ; p<0.0001)$. The proportions of CAP patients among virus and bacteria group were $60.0 \%(87 / 145)$ and $35.9 \%$ (23/64), respectively. The corresponding proportions of AECOPD patients were $26.2 \%(38 / 145)$ and $32.8 \%(21 / 64)$, and $13.7 \%$ (20/145) and 31.3\% (20/64) for acute exacerbation of bronchiectasis patients, 
respectively. Both median PCT and CRP were significantly lower in the virus group than those in the bacteria group $(0.1 \mathrm{ng} / \mathrm{mL}(0.1,0.2)$ versus $0.3 \mathrm{ng} / \mathrm{mL}(0.2,0.7) ; \mathrm{p}<0.0001$ and $10.4 \mathrm{mg} / \mathrm{L}(4.0,28.0)$ versus $53.0 \mathrm{mg} / \mathrm{L}$ $(23.0,96.7) ; p=0.0001)$. And median neutrophil count in the virus group was lower than that in the bacteria group $\left(4.4 \cdot 10^{9} / \mathrm{L}(2.7,6.7)\right.$ versus $\left.4.9 \cdot 10^{9} / \mathrm{L}(4.0,7.3) ; \mathrm{p}=0.0087\right)$. 
Table 1

Demographic and clinical characteristics

\begin{tabular}{|c|c|c|c|}
\hline Variable & $\begin{array}{l}\text { Virus } \\
(N=145)\end{array}$ & $\begin{array}{l}\text { Bacteria } \\
(\mathrm{N}=64)\end{array}$ & $P$ value \\
\hline Age (yrs) & $64.0(48.0,78.0)$ & $64.5(54.5,76.0)$ & 0.8319 \\
\hline Gender & $78(53.8)$ & $42(65.6)$ & 0.1820 \\
\hline \multicolumn{4}{|l|}{ Observation } \\
\hline BMI $\left(\mathrm{kg} / \mathrm{cm}^{2}\right)$ & $23.4(20.4,25.9)$ & $22.2(18.6,26.0)$ & 0.3168 \\
\hline Respiratory frequency (bpm) & $20.0(20.0,22.0)$ & $20.0(20.0,21.0)$ & 0.6199 \\
\hline Heart rate (bpm) & $90.0(80.0,100.0)$ & $95.0(80.5,102.5)$ & 0.2724 \\
\hline Fever & $105(72.4)$ & $39(60.9)$ & 0.0985 \\
\hline Cough & $142(97.9)$ & $63(98.4)$ & 0.8018 \\
\hline Chest pain & $36(24.8)$ & $15(23.4)$ & 0.8293 \\
\hline Headache & $53(36.6)$ & $12(18.8)$ & 0.0104 \\
\hline Rhinorrhea & $80(55.2)$ & $13(20.3)$ & $<.0001$ \\
\hline Final diagnosis & & & $<.0001$ \\
\hline CAP & $87 / 145(60.0)$ & 23/64 (35.9) & \\
\hline AECOPD & $38 / 145(26.2)$ & $21 / 64(32.8)$ & \\
\hline $\mathrm{AE}$ of bronchiectasis & 20/145 (13.7) & 20/64 (31.3) & \\
\hline Dyspnea & $110(75.9)$ & $53(82.8)$ & 0.2636 \\
\hline Diarrhea & $25(17.2)$ & $6(9.4)$ & 0.1403 \\
\hline \multicolumn{4}{|l|}{ Comorbidity (\%) } \\
\hline Cardiovascular disease & $66(45.5)$ & $32(50.0)$ & 0.5495 \\
\hline Diabetes & $32(22.1)$ & $19(29.7)$ & 0.2372 \\
\hline Renal disease & $9(6.2)$ & $3(4.7)$ & 0.6577 \\
\hline Liver disease & $2(1.4)$ & $1(1.6)$ & 0.9189 \\
\hline Cancer & $9(6.2)$ & $4(6.3)$ & 0.2493 \\
\hline
\end{tabular}

$A E$, acute exacerbation; AECOPD, acute exacerbation of chronic obstructive pulmonary disease; CAP, community-acquired pneumonia;

Data are presented as median (interquartile range) for continuous variables and as percent for categorical variables.

Categorical variables were compared using $\chi^{2}$ tests, and continuous variables were compared using Wilcoxon rank-sum test or Student's t-test. 


\begin{tabular}{|c|c|c|c|}
\hline Variable & $\begin{array}{l}\text { Virus } \\
(N=145)\end{array}$ & $\begin{array}{l}\text { Bacteria } \\
(\mathrm{N}=64)\end{array}$ & $P$ value \\
\hline Current smoker & $24(16.6)$ & $10(15.6)$ & 0.8671 \\
\hline Influenza vaccine( $(\mathbb{1}$ year) & $14(9.7)$ & $11(17.2)$ & 0.1219 \\
\hline \multicolumn{4}{|l|}{ Laboratory test } \\
\hline White blood cell count $\left({ }^{*} 10^{9} / \mathrm{L}\right)$ & $6.8(4.8,9.5)$ & $7.2(5.8,9.7)$ & 0.0885 \\
\hline Lymphocyte count $\left(* 10^{9} / \mathrm{L}\right)$ & $1.2(0.8,1.7)$ & $1.3(0.9,1.8)$ & 0.1523 \\
\hline Neutrophil count $\left({ }^{\star} 10^{9} / \mathrm{L}\right)$ & $4.4(2.7,6.7)$ & $4.9(4.0,7.3)$ & 0.0087 \\
\hline Procalcitonin(ng/mL) & $0.1(0.1,0.2)$ & $0.3(0.2,0.7)$ & $<.0001$ \\
\hline C-reactive protein $(\mathrm{mg} / \mathrm{L})$ & $10.4(4.0,28.0)$ & $53.0(23.0,96.7)$ & 0.0001 \\
\hline \multicolumn{4}{|c|}{$\begin{array}{l}\text { AE, acute exacerbation; } A E C O P D \text {, acute exacerbation of chronic obstructive pulmonary disease; CAP, } \\
\text { community-acquired pneumonia; }\end{array}$} \\
\hline \multicolumn{4}{|c|}{$\begin{array}{l}\text { Data are presented as median (interquartile range) for continuous variables and as percent for categorical } \\
\text { variables. }\end{array}$} \\
\hline \multicolumn{4}{|c|}{$\begin{array}{l}\text { Categorical variables were compared using } \chi^{2} \text { tests, and continuous variables were compared using } \\
\text { Wilcoxon rank-sum test or Student's t-test. }\end{array}$} \\
\hline
\end{tabular}

When using CRP to discriminate viral from bacteria LRTI, the area under the ROC curve was $0.77(95 \% \mathrm{Cl}, 0.70-$ 0.84), and the optimal CRP cut-off point was $22 \mathrm{mg} / \mathrm{L}$ (Fig. 2A). Regarding PCT, the area under the ROC curve was $0.74(95 \% \mathrm{Cl}, 0.66-0.82)$, and the optimal PCT cut-off point was $0.18 \mathrm{ng} / \mathrm{mL}$ (Fig. 2B). When CRP ( $\leq$ $22 \mathrm{mg} / \mathrm{L})$ was combined with $\mathrm{PCT}(\leq 0.18 \mathrm{ng} / \mathrm{mL})$ to discriminate viral from bacteria $\mathrm{LRTI}$, the area under the ROC curve was 0.77 (95\% Cl, 0.70-0.84) (Fig. 2C).

We used the optimal cut-off for CRP or PCT combined with headache or rhinorrhea to discriminate viral from bacterial LRTI (Table 2). The areas under the ROC curve were $0.81(95 \% \mathrm{Cl}, 0.75-0.87)$ and $0.80(95 \% \mathrm{Cl}, 0.74-$ $0.86)$ respectively when $\mathrm{CRP}(\leq 22 \mathrm{mg} / \mathrm{L})$ or $\mathrm{PCT}(\leq 0.18 \mathrm{ng} / \mathrm{mL})$ was combined with rhinorrhea, which were better than those alone or combined with headache. When CRP $(\leq 22 \mathrm{mg} / \mathrm{L}), \mathrm{PCT}(\leq 0.18 \mathrm{ng} / \mathrm{mL})$ and rhinorrhea were combined together, the area under the ROC curve was $0.86(95 \% \mathrm{Cl}, 0.80-0.91)$, which were statistically significant higher than that when $\mathrm{CRP}(\leq 22 \mathrm{mg} / \mathrm{L})$ or PCT $(\leq 0.18 \mathrm{ng} / \mathrm{mL})$ was combined with rhinorrhea when distinguish viral or bacterial LRTI $(p=0.0107$ and $p=0.0205)$. 
Table 2

Sensitivity, specificity, positive predictive value (PPV) and negative predictive value (NPV) for optimal cut-off values of CRP and PCT level to differentiate viral from bacterial LRTI

\begin{tabular}{|c|c|c|c|c|c|c|c|}
\hline & CRP cut- & If level & & PCT cut-off & vel & & $\begin{array}{l}\text { CRP and } \\
\text { PCT cut- } \\
\text { off level }\end{array}$ \\
\hline & $\begin{array}{l}\leq \\
22 \mathrm{mg} / \mathrm{L} \\
\text { alone }\end{array}$ & $\begin{array}{l}\leq \\
22 \mathrm{mg} / \mathrm{L} \\
\text { and } \\
\text { Headache }\end{array}$ & $\begin{array}{l}\leq 22 \mathrm{mg} / \mathrm{L} \\
\text { and } \\
\text { Rhinorrhea }\end{array}$ & $\begin{array}{l}\leq \\
0.18 \mathrm{ng} / \mathrm{mL} \\
\text { alone }\end{array}$ & $\begin{array}{l}\leq \\
0.18 \mathrm{ng} / \mathrm{mL} \\
\text { and } \\
\text { Headache }\end{array}$ & $\begin{array}{l}\leq \\
0.18 \mathrm{ng} / \mathrm{mL} \\
\text { and } \\
\text { Rhinorrhea }\end{array}$ & $\begin{array}{l}\mathrm{CRP} \leq \\
22 \mathrm{mg} / \mathrm{L} \\
\text { combined } \\
\mathrm{PCT} \leq \\
0.18 \mathrm{ng} / \mathrm{mL} \\
\text { and } \\
\text { Rhinorrhea }\end{array}$ \\
\hline Sensitivity & $\begin{array}{l}0.71 \\
(0.64- \\
0.78)\end{array}$ & $\begin{array}{l}0.71 \\
(0.64- \\
0.78)\end{array}$ & $\begin{array}{l}0.90 \\
(0.85- \\
0.95)\end{array}$ & $\begin{array}{l}0.68 \\
(0.60- \\
0.76)\end{array}$ & $\begin{array}{l}0.68 \\
(0.60- \\
0.76)\end{array}$ & $\begin{array}{l}0.86 \\
(0.80- \\
0.92)\end{array}$ & $\begin{array}{l}0.73 \\
(0.66- \\
0.80)\end{array}$ \\
\hline Specificity & $\begin{array}{l}0.77 \\
(0.67- \\
0.87)\end{array}$ & $\begin{array}{l}0.77 \\
(0.67- \\
0.87)\end{array}$ & $\begin{array}{l}0.63 \\
(0.51- \\
0.75)\end{array}$ & $\begin{array}{l}0.78 \\
(0.68- \\
0.88)\end{array}$ & $\begin{array}{l}0.78 \\
(0.68- \\
0.88)\end{array}$ & $\begin{array}{l}0.61 \\
(0.49- \\
0.73)\end{array}$ & $\begin{array}{l}0.88 \\
(0.80- \\
0.96)\end{array}$ \\
\hline PPV & $\begin{array}{l}0.87 \\
(0.81- \\
0.93)\end{array}$ & $\begin{array}{l}0.87 \\
(0.81- \\
0.93)\end{array}$ & $\begin{array}{l}0.84 \\
(0.78- \\
0.90)\end{array}$ & $\begin{array}{l}0.88 \\
(0.81- \\
0.94)\end{array}$ & $\begin{array}{l}0.88 \\
(0.81- \\
0.94)\end{array}$ & $\begin{array}{l}0.83 \\
(0.77- \\
0.89)\end{array}$ & $\begin{array}{l}0.93 \\
(0.88- \\
0.98)\end{array}$ \\
\hline NPV & $\begin{array}{l}0.54 \\
(0.44- \\
0.65)\end{array}$ & $\begin{array}{l}0.54 \\
(0.44- \\
0.65)\end{array}$ & $\begin{array}{l}0.73 \\
(0.61- \\
0.84)\end{array}$ & $\begin{array}{l}0.52 \\
(0.42- \\
0.61)\end{array}$ & $\begin{array}{l}0.52 \\
(0.42- \\
0.61)\end{array}$ & $\begin{array}{l}0.65 \\
(0.53- \\
0.77)\end{array}$ & $\begin{array}{l}0.59 \\
(0.49- \\
0.69)\end{array}$ \\
\hline AUC & $\begin{array}{l}0.74 \\
(0.68- \\
0.80)\end{array}$ & $\begin{array}{l}0.78 \\
(0.71- \\
0.84)\end{array}$ & $\begin{array}{l}0.81 \\
(0.75- \\
0.87)^{*}\end{array}$ & $\begin{array}{l}0.73 \\
(0.67- \\
0.79)\end{array}$ & $\begin{array}{l}0.75 \\
(0.69- \\
0.82)\end{array}$ & $\begin{array}{l}0.80 \\
(0.74- \\
0.86)^{\#}\end{array}$ & $\begin{array}{l}0.86 \\
(0.80- \\
0.91)^{\&}\end{array}$ \\
\hline
\end{tabular}

\section{Discussion}

With etiologic detection approach covering relatively wide spectrum of pathogens in our study, we found that either CRP $\leq 22 \mathrm{mg} / \mathrm{L}$ or PCT $\leq 0.18 \mathrm{ng} / \mathrm{mL}$ combined with rhinorrhea could discriminate viral from bacterial infection in hospitalized non-ICU adults with LRTI, which has rarely been explored in adults. When CRP $\leq$ $22 \mathrm{mg} / \mathrm{L}, \mathrm{PCT} \leq 0.18 \mathrm{ng} / \mathrm{mL}$ and rhinorrhea were combined together, discrimination of viral from bacterial infection can be further improved.

For many years, physicians hoped to find a marker that could help discriminating bacterial infection. CRP is an inflammatory marker, which was considered to be able to distinguish between viral and bacterial infections in 1990s.[13]'[14] But with the relative progress of detection technology, more studies thought CRP could not distinguish viral from bacterial infection.[11]'[15]'[16] Review these studies, most of them were conducted among paediatric patients, and the pathogen detection test have low sensitivity and covered limited pathogen. In this study of adults hospitalized with LRTI, we used RT-PCR and multiple nested PCR (FilmArray Respiratory Panel) testing, which were highly sensitive and accurate for the diagnosis of microbial etiology to detect viruses 
and atypical bacteria. Furthermore, the types of pathogens we detected were very comprehensive. Based on this, we suggested that our grouping was more accurate and the results were more credible than those of previous studies. We found the optimal CRP cut-off point was $22 \mathrm{mg} / \mathrm{L}$, but which alone can not identify viral or bacteria infection in adult hospitalized LRTI patients.

PCT is a widely used and recognized biomarker of bacterial infection. Though PCT can guide antibiotic use in respiratory tract infections that had been widely adopted throughout the world,[17] some recently published studies found PCT could not distinguish viral and bacterial infections.[8]'[18] Self`s study used sensitive and widely available etiological detection methods found no procalcitonin threshold perfectly discriminated between viral and bacterial pathogens.[8] A meta-analysis found the sensitivity and specificity of PCT were 0.55 and 0.76 to distinguish viral from bacteria for CAP patients, which could be not reliable evidence either to mandate administration of antibiotics or to enable withholding such treatment in patients with CAP.[18] Our result showed the optimal PCT cut-off point was $0.18 \mathrm{ng} / \mathrm{mL}$ and it may not be an ideal marker to distinguish viral or bacterial infections. And this viewpoint was consistent with Self's study. Therefore, we thought using PCT alone to identify bacterial or viral infections and to guide the use of antibiotics should be cautious.

With increased interest in PCT research, many studies have shown that CRP is inferior to PCT in identifying bacterial or viral infections.[6],[19],[16] In our study, we found that CRP is non-inferior to PCT in differentiating viral from bacterial infection in LRTI patients. Recently, one RCT found that CRP-guided prescribing of antibiotics for AECOPD resulted in a lower percentage of patients, with no evidence of harm.[4] Another study showed that the provision of PCT assay results in addition to usual care did not result in lower use of antibiotics than usual care among patients with suspected LRTI.[20] Combined with our result, we need to further examine the importance of CRP in identifying viral infections and guiding antibiotic use for it is more available and cheaper than PCT.

The most important finding of this study was that CRP $\leq 22 \mathrm{mg} / \mathrm{L}$ or PCT $\leq 0.18 \mathrm{ng} / \mathrm{mL}$ combined with rhinorrhea could help to discriminate bacterial or viral infection, which was firstly reported among adults with LRTI in our consciousness. A study among children found that compared to CRP $\geq 72 \mathrm{mg} / \mathrm{L}$ alone, CRP $\geq$ $72 \mathrm{mg} / \mathrm{L}$ combined with symptoms (including rhinorrhea) could improve the specificity and PPV in discriminating bacterial from viral pneumonia.[11] Some reasons could explain that the CRP optimal cut-off point of our study is lower than Bhuiyan`s[11]. First, the types of patients and diseases were different between two studies. Second, the proportion of patients who received antibiotic therapy was high before hospitalization and onset of illness to admission was long (7days) in our study, which may influence CRP value.[12] Though antiviral drugs and virus detection methods are limited clinically, clinicians should raise awareness if LRTI patient had low CRP or PCT combined with rhinorrhea and have more confidence in stopping or degradation of an antimicrobial drugs.

Our study has a number of limitations. Firstly, it is a reanalysis of a previous RCT, and not all enrolled patients received the FilmArray Respiratory Panel test. Secondly, quite a large proportion of patients who had no pathogen detected were excluded from current analysis although we did an etiology-based study. Thirdly, the study was conducted in general wards, without including patients from ICUs. Because of above limitations, extrapolation of our results should be carefully interpreted. We need further deep research to verify its accuracy in the future. 


\section{Conclusion}

Either CRP $\leq 22 \mathrm{mg} / \mathrm{L}$ or PCT $\leq 0.18 \mathrm{ng} / \mathrm{mL}$ combined with rhinorrhea could help distinguish viral from bacterial infection in hospitalized non-ICU adults with LRTI. When CRP $\leq 22 \mathrm{mg} / \mathrm{L}, \mathrm{PCT} \leq 0.18 \mathrm{ng} / \mathrm{mL}$ and rhinorrhea were combined together, discrimination of viral from bacterial infection in non-ICU of hospitalized adults with LRTI can be further improved.

\section{Abbreviations}

\begin{tabular}{|ll|}
\hline CRP & C-reactive protein \\
\hline PCT & Procalcitonin \\
\hline LRTI & Lower respiratory tract infection \\
\hline ICU & Intensive care unit \\
\hline ROC & Receiver operating characteristic \\
\hline RCT & Randomized controlled trial \\
\hline CJFH & China-Japan Friendship Hospital \\
\hline CAP & Community acquired pneumonia \\
\hline AECOPD & Acute exacerbation of chronic obstructive pulmonary disease \\
\hline MP & Mycoplasma pneumoniae \\
\hline CP & Chlamydophila pneumoniae \\
\hline RT-PCR & Reverse transcriptase polymerase chain reaction \\
\hline PPV & Positive predictive value \\
\hline NPV & Negative predictive value \\
\hline Cls & Confidence intervals \\
\hline AUCs & Areas under the curve \\
\hline
\end{tabular}

\section{Declarations}

Ethics approval and consent to participate

The study was approved by the ethics committee of CJFH (2017-29).

Consent for publication

Not applicable.

Availability of data and materials 
As another investigations involving this data are in progress, so the data will not be available to others. When all investigations are finished, data might be made available.

\section{Competing interests}

The authors of the manuscript declare no conficts of interest and take sole responsibility for the writing and content of the manuscript. None of the authors have been involved in legal or regulatory matters related to the contents of this paper.

\section{Funding}

This work was supported by the National Science Grant for Distinguished Young Scholars (grant number 81425001/H0104) and Chinese Academy of Medical Science Innovation Fund for Medical Sciences (2018-I2M1-003).

\section{Authors` contributors}

Shengchen DUAN designed the trial , reviewed the medical literature, participated in the data analysis and interpretation, and drafted and wrote the manuscript.

Xiaoying GU and Guohui FAN maked the statistical analysis of data.

Fei Zhou participated in the data analysis and interpretation.

Guangfa Zhu participated in the interpretation.

Bin CAO conceived and designed the trial, supervised the trial and allocated staff, participated in the data analysis and interpretation.

All authors reviewed and contributed to the report during its development.

\section{Acknowledgments}

We thank all the patients and clinical staff at the general wards of Respiratory Critical Medical Department, Traditional Chinese Medicine (TCM) lung disease department, Infectious Disease Department and laboratory of Clinical Microbiology and Infectious Diseases in China-Japan Friendship Hospital, including clinicians, nurses, and laboratory technicians.

\section{References}

1. World Health Organization. World health report: the ten most common infections. http://www.who.int/mediacentre/factsheets/fs310/en. (accessed May 09, 2021).

2. Crotty MP, Meyers S, Hampton N, Bledsoe S, Ritchie DJ, Buller RS, et al. Impact of antibacterials on subsequent resistance and clinical outcomes in adult patients with viral pneumonia: An opportunity for stewardship. Crit Care [Internet]. Critical Care; 2015;19:1-11. Available from: http://dx.doi.org/10.1186/s13054-015-1120-5. 
3. News release, Food and. Administration D, Spring S, February MD 23 2017. Tract, FDA clears test to help manage antibiotic treatment for lower respiratory The infections and sepsis. https//

Www.fda.gov/NewsEvents/Newsroom/ Press. (accessed May 09, 2021).

4. Butler CC, Gillespie D, White P, Bates J, Lowe R, Thomas-Jones E, et al. C-reactive protein testing to guide antibiotic prescribing for COPD exacerbations. N Engl J Med. 2019;381:111-20.

5. García Vázquez E, Martínez JA, Mensa J, Sánchez F, Marcos MA, de Roux A, et al. C-reactive protein levels in community-acquired pneumonia. Eur Respir J. 2003;21:702-5.

6. Liliana S, 1 France Gauvin, 2 Devendra K Amre, 2 Patrick Saint-Louis 3 and Jacques Lacroix2. Serum Procalcitonin and C-Reactive Protein Levels as Markers of Bacterial Infection: A Systematic Review and Meta-analysis. Clin Infect Dis. 2004;39:206-17.

7. Gilbert DN. Procalcitonin as a biomarker in respiratory tract infection. Clin Infect Dis. 2011;52:346-50.

8. Self WH, Balk RA, Grijalva CG, Williams DJ, Zhu Y, Anderson EJ, et al. Procalcitonin as a Marker of Etiology in Adults Hospitalized with Community-Acquired Pneumonia. Clin Infect Dis. 2017;65:183-90.

9. Cuquemelle E, Soulis F, Villers D, Roche-Campo F, Ara Somohano C, Fartoukh M, et al. Can procalcitonin help identify associated bacterial infection in patients with severe influenza pneumonia? A multicentre study. Intensive Care Med. 2011;37:796-800.

10. Rodríguez AH, Avilés-Jurado FX, Díaz E, Schuetz P, Trefler SI, Solé-Violán J, et al. Procalcitonin (PCT) levels for ruling-out bacterial coinfection in ICU patients with influenza: A CHAID decision-tree analysis. J Infect. 2016;72:143-51.

11. Bhuiyan MU, Blyth CC, West R, Lang J, Rahman T, Granland C, et al. Combination of clinical symptoms and blood biomarkers can improve discrimination between bacterial or viral community-acquired pneumonia in children. BMC Pulm Med BMC Pulmonary Medicine. 2019;19:1-9.

12. Shengchen D, Gu X, Fan G, Sun R, Wang Y, Yu D, et al. Evaluation of a molecular point-of-care testing for viral and atypical pathogens on intravenous antibiotic duration in hospitalized adults with lower respiratory tract infection: a randomized clinical trial. Clin Microbiol Infect. 2019;25:1415-21.

13. Korppi M, Kröger L. C-reactive protein in viral and bacterial respiratory infection in children. Scand J Infect Dis. 1993;25:207-13.

14. Clyne B, Olshaker JS. The C-reactive protein. J Emerg Med. 1999;17:1019-25.

15. Thomas J, Pociute A, Kevalas R, Malinauskas M, Jankauskaite L. Blood biomarkers differentiating viral versus bacterial pneumonia aetiology: A literature review. Ital J Pediatr Italian Journal of Pediatrics. 2020;46:1-10.

16. Principi N, Esposito S. Biomarkers in pediatric community-acquired pneumonia. Int J Mol Sci. 2017;18:1-9.

17. Schuetz P. Procalsitonin for Diagnosis of Infection and Guide to Antibiotic Decision. BMC Med J. 2011;107:1-9.

18. Kamat IS, Ramachandran V, Eswaran H, Guffey D, Musher DM. Procalcitonin to distinguish viral from bacterial pneumonia: A systematic review and meta-analysis. Clin Infect Dis. 2020;70:538-42.

19. Tanrıverdi H, Örnek T, Erboy F, Altınsoy B, Uygur F, Atalay F, et al. Vergleich der diagnostischen Wertigkeit von Procalcitonin, C-reaktivem Protein und vom Neutrophilen/Lymphozyten Quotienten bei der Vorhersage von bakteriellen Infekten bei hospitalisierten Patienten mit akuter Exazerbation einer chronisch obstruktiven Lun. Wien Klin Wochenschr. 2015;127:756-63.

Page 12/14 
20. Huang DT, Yealy DM, Filbin MR, Brown AM, Chang CCH, Doi Y, et al. Procalcitonin-guided use of antibiotics for lower respiratory tract infection. N Engl J Med. 2018;379:236-49.

\section{Figures}

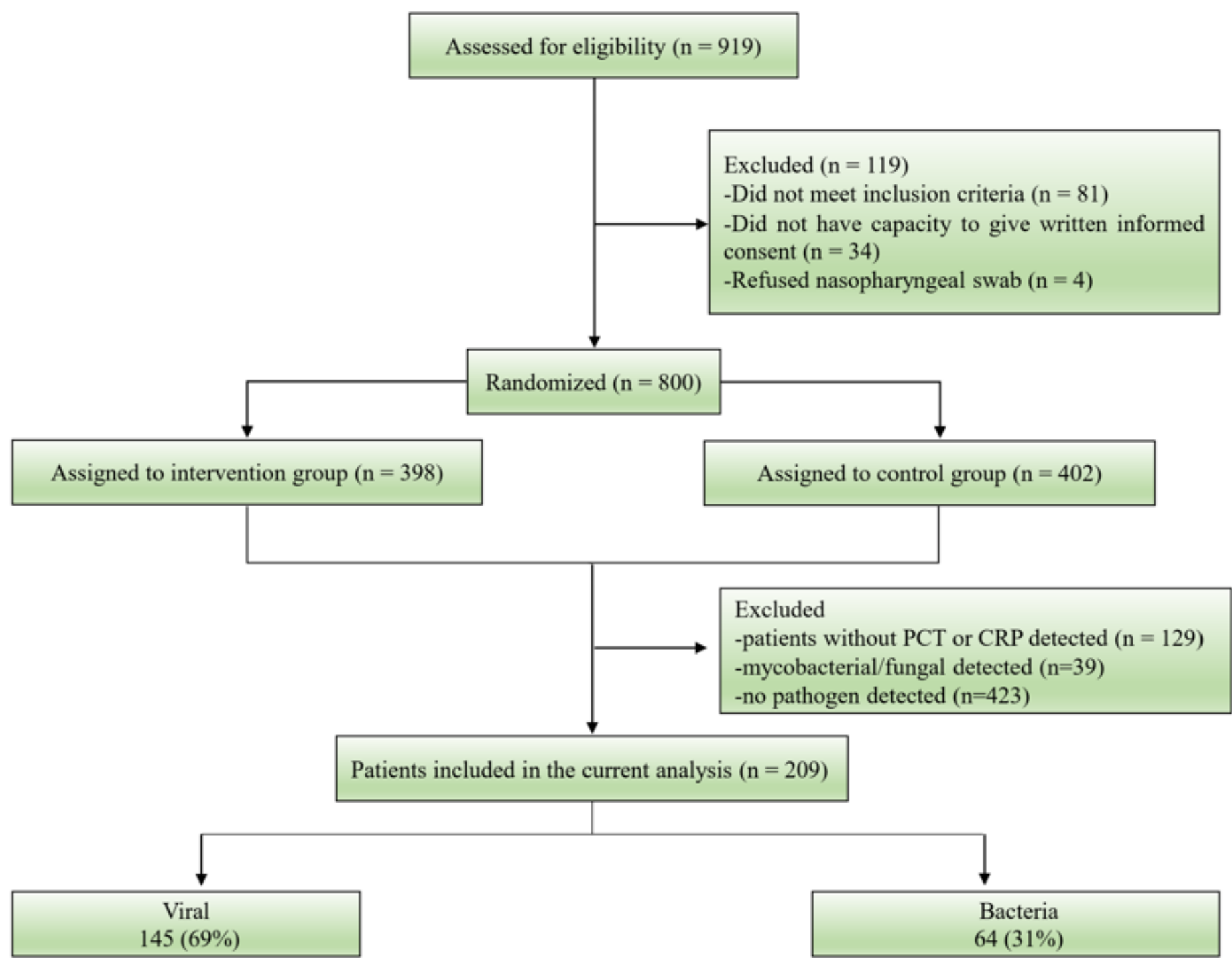

Figure 1

Flow diagram of patients included in the study. 

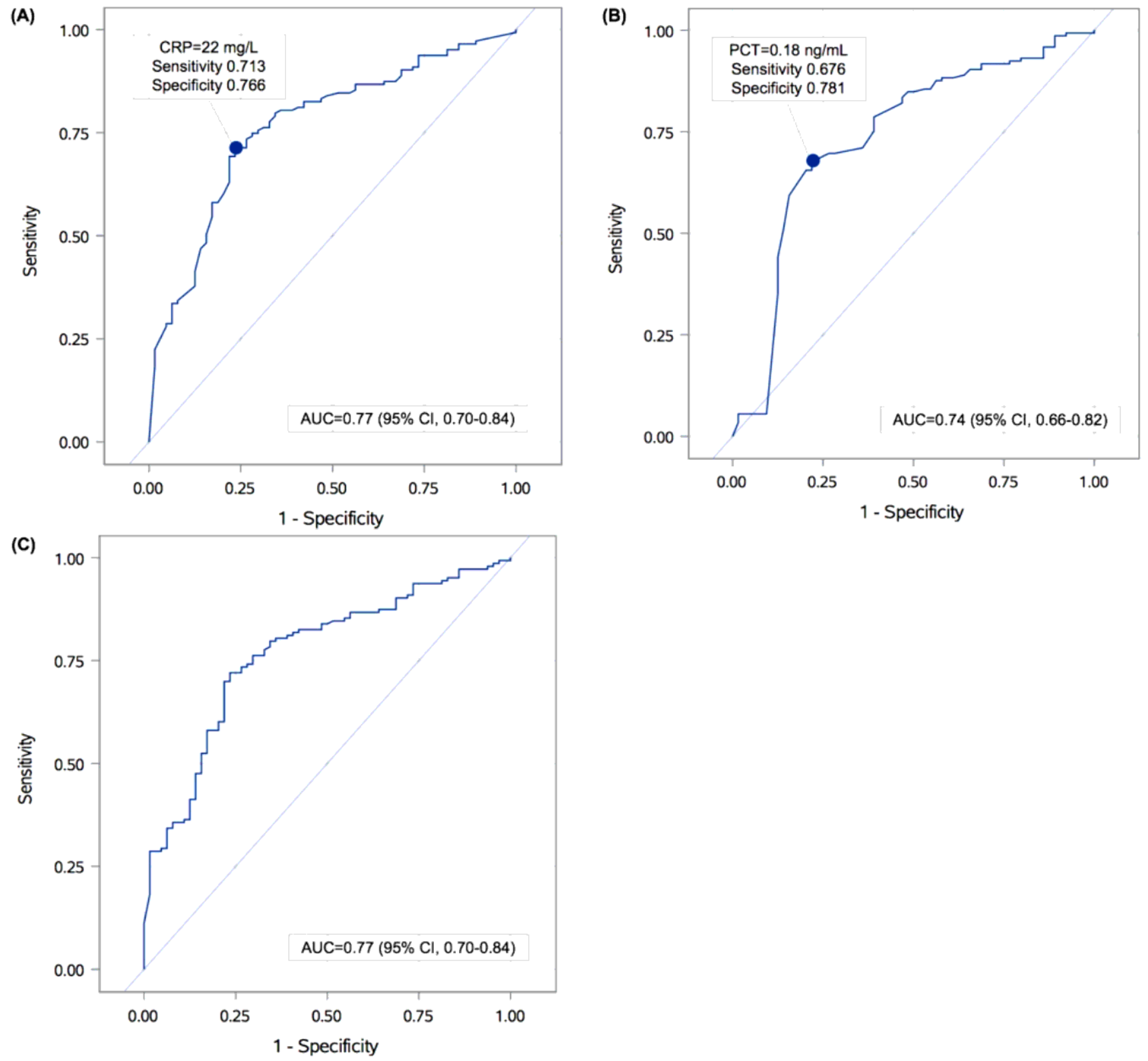

Figure 2

When using CRP to discriminate viral from bacteria LRTI, the area under the ROC curve was $0.77(95 \% \mathrm{Cl}, 0.70$ 0.84), and the optimal CRP cut-off point was $22 \mathrm{mg} / \mathrm{L}$ (Figure $2 \mathrm{~A}$ ). Regarding PCT, the area under the ROC curve was $0.74(95 \% \mathrm{Cl}, 0.66-0.82)$, and the optimal PCT cut-off point was $0.18 \mathrm{ng} / \mathrm{mL}$ (Figure $2 \mathrm{~B}$ ). When CRP $(\leq 22 \mathrm{mg} / \mathrm{L})$ was combined with $\mathrm{PCT}(\leq 0.18 \mathrm{ng} / \mathrm{mL})$ to discriminate viral from bacteria LRTI, the area under the ROC curve was 0.77 (95\% Cl, 0.70-0.84) (Figure 2C). 